\title{
Editorial \\ Sustainable Development and Renewable Energy: A New View to a Global Problem
}

\author{
Alexey Mikhaylov (D)
}

check for

updates

Citation: Mikhaylov, A. Sustainable Development and Renewable Energy: A New View to a Global Problem. Energies 2022, 15, 1397. https:// doi.org/10.3390/en15041397

Received: 7 February 2022

Accepted: 11 February 2022

Published: 15 February 2022

Publisher's Note: MDPI stays neutral with regard to jurisdictional claims in published maps and institutional affiliations.

Copyright: (C) 2022 by the author. Licensee MDPI, Basel, Switzerland. This article is an open access article distributed under the terms and conditions of the Creative Commons Attribution (CC BY) license (https:/ / creativecommons.org/licenses/by/ $4.0 /)$.
Research Center of Monetary Relations, Financial University under the Government of the Russian Federation, 124167 Moscow, Russia; ayumihajlov@fa.ru; Tel.: +7-901-908-9817

\section{Introduction}

Sustainable development and renewable energy has become the main global trend after the COVID-19 pandemic in 2020-2022. International companies producing renewable energy have the potential for growth, that is, an increase in production, and profits have been confirmed. Moreover, the bioenergy and solar energy sector has shown a significant increase in profits against the background of the crisis. This is primarily due to the problems caused by the crisis for its direct competitors.

In such conditions, there is definitely an incentive for the growth of the stock prices of companies operating in the field of bio and solar energy, as one of the advanced areas of renewable energy. Since bio and solar energy is a renewable-energy sector with one of the highest cash flows, the rise in stock prices is obvious, as is a short-term price correction after a rapid increase over the following weeks.

It is assumed that the growth in the value of renewable-energy shares will be higher than the market average relative to that for other companies with equally high balance sheets and capitalization. Nevertheless, pressure from companies operating in the field of traditional energy cannot be ruled out, since traditional energy is cheaper and much more adapted to changes in supply and demand in the market.

Renewable-energy shares are likely to experience the effect of previous trading periods in the near future. Despite the already-significant underestimation of the shares, prices will fluctuate in the near future under the influence of medium-term trends; however, closer to the end of 2022, the market price of the stock is projected to approach a fair price.

The turning point for renewable energy should be the release of several reports with a positive trend of changes. Such an outcome is most likely, based on the decline in a company's profitability during the crisis period. Thus, coming out of the crisis, the company will show very high results as a percentage of previous periods, which will provide an incentive to investors to invest in this company, and this, in turn, will bring an additional flow of free cash, which is necessary for moving away from the range and moving to the revaluation of shares, relative to the changed fundamentals.

Further research will consider the application of this forecasting method for the shares of companies not related to alternative energy. The most likely hypothesis for future research will be the confirmation or refutation of the effectiveness of the method for the entire financial market as a whole, regardless of the company's field of activity.

This is due to the share of buyers and sellers of shares trading solely on the basis of the technical component of the asset. Such exchange players in a small area of the tipping point often cannot correctly determine the direction of the future trend, and therefore, the maximum and minimum values rush in opposite directions. However, there are periods on the chart where the trend changes, and the values of the minima and maxima practically do not change. Such a process is due to the low probability of an event opposite to the one that will occur; however, as is well-established, there will always be traders who decide to take a higher risk in the hope of obtaining a higher profit. Thus, the values of the minima and maxima, although they are directly dependent on the closing prices, are an independent 
unit with a separate dependence on each other. The interdependence of lows and highs is determined by the stage of the trend and the predictability of the behavior of the company's stock prices.

\section{A Short Review of the Contributions in This Issue}

As far as energy efficiency is concerned, one article addresses appropriate integrated technologies.

Nurgalieva et al. [1] show that, during the final stage of oil-field development, there may be several occurrences, including the formation of asphalt, resin, and paraffin deposits (ARPD). Appropriate integrated technologies are needed to remove already-formed deposits and prevent the formation of ARPD. This article is devoted to the complex technology of oil-field development. This technology combines both the removal of scale deposits and the elimination of scale formation in the wellbore formation zone (BHFZ) system. This article discusses the calculation of the parameters for the process of supplying an ARPD inhibitor to the BHFZ. This technology includes the process of removing ARPD by flushing the wells and injecting the developed ARPD solvent into the BHFZ. In addition, deposit-prevention technology has been added. This is provided by compressing the ARPD inhibitor and pumping it out by pumping the liquid being sold with five to ten times its volume. This article provides detailed calculation methodologies and provides solvent and inhibitor injection schemes.

In the article by Dacko et al. [2], expert analysis is applied. The idea of sustainability has been exerting an impact on public awareness for nearly five decades. However, representatives of various sciences interpret it in many different ways, and there were several hundred definitions of it already at the end of the 20th century. There is no doubt that a proper understanding of the essence and meaning of sustainable development by opinion leaders representing various scientific disciplines determines transformations in particular sectors of the economy, especially in the energy sector. Economics, which considers the relationship between the economy and the environment, seems to have a special role with regard to this issue. Models and concepts of managing limited environmental resources are considered based on this science. Thus, economists have a type of greater responsibility for the shape and direction of development, and, especially, for whether it will be durable and balanced. With these issues in mind, the aim of this paper is to review and systematize the opinions of Polish experts on the concept of sustainable development and to indicate the most important parameters that define it. The paper presents the results of an opinion survey of 105 experts affiliated with a wide variety of institutions. The respondents represented economic, technical, social, and natural sciences.

Thus, the water and waste services were analyzed by Sanchez-Hernandez et al. [3] using advanced statistical methods. Access to safe drinking water is essential for good health, a basic human right, and a component of effective policies for health protection. Improving the quality of local public water and waste services is one of the United Nations' Sustainable Development Goals (Goal 6: Clean Water and Sanitation). This study aimed to determine the degree of satisfaction of domestic users who received services related to water and waste in municipalities with fewer than 20,000 inhabitants in the province of Badajoz (Spain). We carried out this research because the perception of municipal services provided by the public administration is usually negative and deficient. The case study PROMEDIO, the consortium formula, is described as a successful partnership to improve the quality of local public water and waste services. For this purpose, a detailed analysis of the different aspects involved in the relationship between the users and the services provided was carried out. The consortium was found to increase citizens' satisfaction with the services provided, given the close relationship between the municipality and the users.

Furthermore, as shown by Tamashiro et al. [4], due to the rapid changes in the energy situation on a global scale, the amount of RES installed using clean renewable-energy sources such as photovoltaic (PV) and wind-power generators (WGs) is rapidly increasing. As a result, there has been a great deal of research aimed at promoting the adoption of 
renewable energy. Research on demand-side management (DSM) has also been important in promoting the adoption of RES. However, the massive introduction of PVs has changed the shape of the demand curve for electricity, which significantly impacts the operational planning of thermal generators. Therefore, this paper proposes an advanced direct load control (ADLC) model to temporarily shut down the electric connection between the power grid and smart houses (SHs). The most important feature of the proposed model is that it temporarily shuts down the electric connection with the power grid. The shutdown is performed twice to increase the load demand during daytime hours and reduce the peak load during night-time hours. The proposed model also promotes the self-consumption of the generated power during the shutdown period, which is expected to reduce the operating cost. This paper considers six case studies for $\mathrm{SH}$, and the operational costs and carbon dioxide emissions are compared and discussed. The results show that the $\mathrm{SH}$ with ADLC successfully reduces the operating costs and carbon dioxide emissions.

When making a forecast for a renewable energy, we should not forget the importance of analyzing the state of its customers, since they largely determine the future of the renewable energy [5-10].

A significant indicator for evaluating the sustainability of renewable energy is the share of renewable energy in global demand. It is worth noting that economic and statistical forecasts for short periods of time, for example, for one or a few years, are very important for global demand in renewable energy [11-16].

\section{Conclusions}

As mentioned earlier, the area formed by the minimum and maximum becomes smaller as the certainty in the behavior of the prices of the future period increases. This issue was discussed within the framework of the trend stage and tipping points, but the same is true for stocks with more or less risk, in general. Thus, renewable-energy production, according to reports on the renewable-energy sector's activities during the pandemic crisis period, seems to be a more unstable form of energy compared to its direct competitor, although, before the crisis, it was the opposite. Moreover, this is the reason for the longer sideways movement of prices in the forecast for the coming year. If many renewable-energy producers' reports are generally positive compared to those for the previous pre-crisis period, then a small number of renewable-energy producers with negative data, in some cases, prevail over those with positive ones. However, renewable energy is a dynamic industry with many reserves that have allowed it to support renewable energy for a long time during the crisis.

Funding: This research received no external funding.

Informed Consent Statement: Not applicable.

Data Availability Statement: Not applicable.

Acknowledgments: The author is grateful to the MDPI Publisher for the invitation to act as guest editor of this Special Issue and is indebted to the editorial staff of Energies for their kind co-operation, patience, and committed engagement. We would like to give special thanks to Laboratory Assistants of the Financial University under the Government of the Russian Federation (Artur Meynkhard, Anton Lisin, and Evgeny Lopatin) for technical support.

Conflicts of Interest: The authors declare no conflict of interest.

\section{References}

1. Nurgalieva, K.S.; Saychenko, L.A.; Riazi, M. Improving the Efficiency of Oil and Gas Wells Complicated by the Formation of Asphalt-Resin-Paraffin Deposits. Energies 2021, 14, 6673. [CrossRef]

2. Dacko, M.; Płonka, A.; Satoła, Ł.; Dacko, A. Sustainable Development According to the Opinions of Polish Experts. Energies 2021, 14, 5325. [CrossRef]

3. Sanchez-Hernandez, M.I.; Maldonado-Briegas, J.J.; Sanguino, R.; Barroso, A.; Barriuso, M.C. Users' Perceptions of Local Public Water and Waste Services: A Case Study for Sustainable Development. Energies 2021, 14, 3120. [CrossRef] 
4. Tamashiro, K.; Alharbi, T.; Mikhaylov, A.; Hemeida, A.M.; Krishnan, N.; Lotfy, M.E.; Senjyu, T. Investigation of Home Energy Management with Advanced Direct Load Control and Optimal Scheduling of Controllable Loads. Energies 2021, $14,7314$. [CrossRef]

5. Fu, Z.; Yu, C. Promoting Green Development in China's New Development Stage through Tax Reform. Financ. J. 2021, 13, 44-50.

6. Rezvanov, R. Implementation of International Sustainable Financing Practices into the National Debt System. Can Infrastructure Loans Become Responsible? Financ. J. 2021, 13, 62-78. [CrossRef]

7. Mingaleva, Z.; Starkov, Y. The Role of Environmental Innovation in Green Modernization of Industrial Enterprises. Financ. J. 2021, 13, 79-92. [CrossRef]

8. Gibadullin, A.A.; Morkovkin, D.E.; Milonova, M.V.; Progunova, L.V.; Isaichykova, N.A. Creation of an autonomous energy supply system for isolated territories. J. Phys. Conf. Ser. 2020, 1614, 012025. [CrossRef]

9. Flaksman, A.S.; Mozgovoy, A.I.; Lopatkin, D.S.; Dikikh, V.A.; Shamsov, I.S.; Romanova, J.A.; Morkovkin, D.E.; Bovtrikova, E.V. Prospects for the development of alternative energy sources in the world energy. IOP Conf. Ser. Earth Environ. Sci. 2021, $723,05204$. [CrossRef]

10. Yakovlev, I.A.; Kabir, L.S.; Nikulina, S.I. Changes in Climate Policies and Financial Strategies of Their Implementation in the EU and Russia. Financ. J. 2021, 13, 11-28. [CrossRef]

11. Kranina, E.I. China on the way to achieving carbon neutrality. Financ. J. 2021, 13, 51-61. [CrossRef]

12. Sannikova, L. Legal Framework for Green Finance in the EU and Russia. Financ. J. 2021, 13, 29-43. [CrossRef]

13. Bushukina, V. Specific Features of Renewable Energy Development in the World and Russia. Financ. J. 2021, 13, 93-107. [CrossRef]

14. Arlashkin, I. Clustering of Russian Regions by Level of Debt Sustainability. Financ. J. 2021, 13, 108-124. [CrossRef]

15. Matveeva, N. Legislative Regulation Financial Statement Preparation by Micro Entities: International Experience. Financ. J. 2021, 13, 125-138. [CrossRef]

16. Vinogradova, I. Participatory Budgeting as a Tool Contributing to the Achievement of the Sustainable Development Goals. Financ. J. 2021, 13, 46-60. [CrossRef] 